JSAP: Journal Syariah and Accounting Public

ISSN: 2622-3538

Available Online at https://journal.umgo.ac.id/index.php/JSAP/index

Vol. 4, No. 1 Juli 2021

DOI: $10.31314 /$ jsap.4.1.37-46.2021

\title{
IMPLEMENTASI UNDANG UNDANG NOMOR 6 TAHUN 2014 TENTANG DANA DESA DI PENTADIO TIMUR KECAMATAN TELAGA BIRU
}

\author{
Widya Kurniati Mohi ${ }^{1}$, Dian Hulalata ${ }^{2}$ \\ 1,2, Program Studi Administrasi Publik Fakultas IImu Sosial Universitas Muhammadiyah \\ Gorontalo, Indonesia \\ Email; Widyakurniati@umgo.ac.id
}

Info Artikel: Diterima: 13 Nov. 2019, Disetujui: 17 Februari 2020, Publish 15 Juli 2021

\begin{abstract}
:
This research aims to determine how the implementation of Law Number 6 of 2014 concerning Village Funds in East Pentadio, Telaga Biru District and the use of the Village Fund Budget for the prosperity and welfare of the village community in East Pentadio Village, Telaga Biru District, with a qualitative descriptive research method with The data collection technique is done by using the data collection technique through interviews, observation, and documentation. In this study it can be seen that from four indicators, namely Communication, Resources, Disposition, Bureaucratic Structure to measure the implementation of Law Number 6 of 2014 concerning Village Funds at Pentadio Timur, Telaga Biru District, it can be concluded that all variables are good even though there are still mistakes. One variable that looks unfavorable is: The biroration structure meets the standards but currently shows that there are still disparities in carrying out organizational duties and functions in policy making.
\end{abstract}

Keywords: Implementation, Law, Village Fund

\begin{abstract}
Abstrak:
Penelitian ini bertujuan untuk mengetahui Bagaimana Implementasi Undang Undang Nomor 6 Tahun 2014 Tentang Dana Desa di Pentadio Timur Kecamatan Telaga Biru serta penggunaan Anggaran Dana Desa untuk kemakmuran dan kesejahteraan masayarakat desa di Desa Pentadio Timur Kecamatan Telaga Biru, dengan Metode penelitian yang di guanakan deskriptif kualitatif dengan teknik Pengumpulan data dilakukan dengan Teknik pengumpulan data dilakukan melalui wawancara, observasi, dan dokumentasi. Pada penelitian ini dapat di ketahui bahwa Dari empat indikator yakni Komunikasi, Sumberdaya, Disposisi, Struktur birokrasi untuk mengukur implementasi Undang Undang Nomor 6 Tahun 2014 Tentang Dana Desa di Pentadio Timur Kecamatan Telaga Biru dapat di simpulkan bahwa semua variable, sudah baik meskipun masih ada salah satu variable yang terlihat kurang baik yakni : Struktur birorasi sudah memenuhi standar namun saat ini menunjukkan bahwa masih adanya ketimpangan dalam menjalankan tugas dan fungsi organisasi dalam pengambilan kebijakan.
\end{abstract}

Kata kunci : Implementasi, Undang-Undang, Dana Desa

$\begin{array}{cl}\text { PENDAHULUAN } & \text { batas wilayah yang kewenangan untuk } \\ \text { Desa merupakan kesatuan } & \text { mengatur dan mengurus kepentingan } \\ \text { masyarakat hukum yang memiliki batas- } & \text { masyarakat setempat berdasarkan asal-usul }\end{array}$


dan adat istiadat setempat yang diakui dan dihormati dalam sistem Pemerintahan Negara Kesatuan Republik Indonesia (NKRI). Secara kelembagaan, perwujudan kehidupan demokrasi di desa melalui pembentukan BPD. Badan ini berfungsi sebagai badan pembuat kebijakan dan pengawas pelaksanakan kebijakan desa, sebagaimana diatur dalam Pemendagri Nomor 110 Tahun 2016 pada Pasal 31 ayat 1 yang berfungsi sebagai lembaga legislatif, pengawasan, dan penampung serta penyalur aspirasi

Di tetapkan dan disahkannya Undang Undang Nomor 6 Tahun 2014 tentang Desa. Desa diberikan kesempatan yang besar untuk mengurus tata pemerintahannya sendiri serta pelaksanaan pembangunan untuk meningkatkan kesejahteraan dan kualitas hidup masyarakat desa. Selain itu pemerintah desa diharapkan untuk lebih mandiri dalam megelola pemerintahan dan berbagai sumber daya alam yang dimiliki, termasuk didalamnya pengelolaan keuangan dan kekayaan milik desa. Begitu besar peran yang diterima oleh desa, tentunya disertai dengan tanggung jawab yang besar pula. Oleh karena itu pemerintah desa harus bisa menerapkan prinsip akuntabilitas dalam tata pemerintahannya, dimana semua akhir kegiatan penyelenggaraan pemerintahan desa harus dapat di pertanggungjawabkan kepada masyarakat desa sesuai dengan ketentuan.

Desa yang dimaksud dalam Undangundang Nomor 6 Tahun 2014 adalah desa dan desa adat atau yang disebut atau yang disebut dengan nama lain, selanjutnya disebut Desa, adalah kesatuan masyarakat hukum yang me-miliki batas-batas wilayah yang berwenang untuk mengatur dan mengurus urusan pemerintahan kepentingan masyarakat setempat, berdasarkan prakarsa masyarakat, hak asal-usul, dan/atau hak tradisional yang diakui dan dihormati dalam sistem Pemerintahan Negara Kesatuan Republik Indonesia. Desa sebagai suatu bagian dari sistem pemerintahan Negara Kesatuan Republik Indonesia yang diakui otonominya dan Kepala desa melalui pemerintah desa dapat diberikan penugasan pendelegasian dari pemerintahan ataupun pemerintahan daerah untuk melaksanakan urusan pemerintah tertentu.

Undang-undang Nomor 6 Tahun 2014 tentang Desa Bab I Pasal 1 (14) menyebutkan bahwa "Pemerintahan Daerah adalah Pemerintah Daerah dan Dewan Perwakilan Rakyat Daerah yang menyelenggarakan urusan pemerintahan menurut asas otonomi dan tugas pembantuan dengan prinsip otonomi seluas luasnya dalam sistem dan prinsip Negara Kesatuan Republik Indonesia sebagaimana dimaksud dalam UUD NRI 1945". Sistem pemerintahan Negara Kesatuan Republik Indonesia tujuannya untuk memberikan keleluasaan kepada daerah untuk menyelenggarakan otonomi daerah yang menekankan pada prinsip prinsip demokrasi.

Saaat ini desa tak lebih hanya sekedar menjadi kepanjangan tangan dari pemerintah kabupaten, pemerintah provinsi maupun pemerintah pusat. Pemerintah Desa lebih banyak hanya bertugas sebagai pelaksana pembangunan yang telah didesign oleh pemerintah diatasnya. Mengerjakan proyek yang direncanakan meskipun seringkali kurang bermanfaat bagi masyarakat desa. Sekarang ini regulasi tentang Desa telah diatur khusus, terbitnya UU nomor 6 tahun 2014 tentang Desa menegaskan desa bukan lagi local state government tapi desa sebagai pemerintahan masyarakat, hybrid antara self governing community dan local self government.

Berdasarkan ketentuan Pasal 18 UUD 1945 menegaskan, “(1) Negara Kesatuan 
Republik Indonesia dibagi atas daerahdaerah Provinsi dan daerah Provinsi dibagi atas Kabupaten yang diatur dengan undangundang", (2) Pemerintah daerah provinsi, daerah kabupaten, dan kota mengatur dan mengurus sendiri urusan pemerintahan menurut asas otonomi dan tugas pembantuan. Selanjutnya Pasal 18 (5) yang berbunyi, "Pemerintahan daerah menjalankan otonomi seluas luasnya, kecuali urusan pemerintahan yang oleh undang-undang ditentukan sebagai urusan Pemerintah Pusat".

Berlakunya Undang-undang ini pada prakteknya masyarakat meragukan tugas dan tanggung jawab kepala desa dalam menjalankan perannya sebagai pengelola atas dana yang dianggarkan untuk keperluan pembanguan desa, keraguan mereka terutama pada kekawatiran akan pengelolaan dana yang begitu besar sampai milyaran yang masuk ke desa dengan slogan pemerintah yakni 1 (satu) milyar 1 (satu) desa yang di gulirkan secara bertahap dengan melihat kreteria desa, anggaran untuk desa nantinya akan diberikan langsung $100 \%$ dengan rincian $60 \%$ untuk pemberdayaan masyarakat dan $40 \%$ untuk operasional desa, hal itu pula banyak program di desa yang tumpang tindih dengan pemerintah pusat maupun pemerintah daerah yang dampaknya pada persoalan Hukum, Politik, sosial budaya pada masyarakat yanga awalnya dengan harapan baik namun menjadi keresahan, Sedangkan di internal desa baik dari kelembagaan sebagai unsur pelaksana pengelolaan, pengawasan dana desa yang masih belum sepenuhnya menggunakan prinsip akuntabilitas dan inklusisosial untuk bertanggung jawab pada masyarakat, permasalahan lain belum maksimal kesiapan pemerintah desa khususnya Pentadio Timur dalam pelaksaan Undang-undang tentang desa, serta yang banyak di jumpai di setiap desa masih kurangnya pengetahuan dan sumber daya manusia (SDM) pada pemerintah desa dalam menghadapi tantangan di era globalisasi, rendahnya kwalitas hidup masyarakat yang tercatat kepala keluarga miskin masih banyak di desa, serta kesiapan perangkat desa dalam menjalankan undang-undang tentang desa masih kurang memahami.

Menurut George C. Edward III dalam Subarsono (2006:90) memberikan pandangan bahwa implementasi kebijakan dipengaruhi oleh empat variable, yaitu

(1)Komunikasi,

Komunikasi merupakan alat kebijakan untuk menyampaikan perintah-perintah dan arahan-arahan (informasi) dan sumber pembuat kebijakan kepada mereka-mereka yang diberikan wewenang dan tanggung jawab untuk melaksanakan kebijakan tersebut. Untuk itu perlu memahami arah penyampaian kebijakan. Tipe komunikasi yang diajukan oleh Edward III termasuk pada tipe komunikasi vertikal.

(2)Sumberdaya

Sumber daya merupakan salah satu faktor penting dalam implementasi kebijakan karena bagaimanapun baiknya kebijakan atau program dirumuskan tanpa ada dukungan sumberdaya yang memadai maka kebijakan akan mengalami kebijakan kesulitan dalam mengimplementasikannya. Sumber daya yang dimaksudkan mencakup jumlah staff pelaksana yang memadai dengan keahlian yang memadai, informasi, wewenang atau kewenangan dan fasilitasfasilitas yang diperlukan untuk menjamin kebijakan dijalankan sesuai dengan apa yang diharapkan. Memadai yang dimaksudkan adalah jumlah para pelaksana harus sesuai dengan jumlah tugas yang dibebankan maupun kemampuannya, dan keterampilan yang dimiliki baik teknis 
maupun material. Indikator yang digunakan untuk mengukur keberhasilan implementasi dari sumber daya adalah :

a. Jumlah staff atau pelaksana dan kemampuannya baik secara teknis maupun material

b. Dukungan fasilitas baik berupa dana maupun infrastruktur lainnya dilapangan

c. Wewenang para pelaksana dalam melaksanakan kebijakan.

(3)Disposisi (sikap)

Kemauan atau niat para pelaksana untuk melaksanakan kebijakan, ini seiring dengan apa yang dikemukakan oleh Meter and Horn disposisi yang diartikan sebagai motifasi psikologis para pelaksana untuk melaksanakan kebijakan. Menurutnya ada tiga hal yang terdapat didalam disposisi atau sikap pelaksana yang merupakan unsur penting dalam implementasi yaitu:

a. Penanaman dan pengetahuan para pelaksana terhadap kebijakan

b. Arah respon dari para pelaksana terhadap pelaksana implementasi kebijakan (penerimaan dan penolakan).

c. Insensitas dari respon.

(4) Struktur birokrasi, dan keempat variabel tersebut saling berhubungan satu sama lain.

Meskipun sumber-sumber untuk mengimplementasikan suatu kebijakan sudah mencukupi dan para implementor mengetahui dan bagaimana cara melakukannya, implementasi bisa jadi belum efektif karena ketidak efisienan struktur birokrasi yang ada. Birokrasi merupakan salah satu bahan yang paling sering bahkan secara keseluruhan menjadi pelaksanaan kebijakan..

\section{METODE PENELITIAN}

Pendekatan yang digunakan penulis pada penelitian ini adalah pendekatan penelitian kualitatif. Penelitian kualitatif didefinisikan sebagai suatu proses yang mencoba untuk mendapatkan pemahaman yang lebih baik mengenai kompleksitas yang ada dalam interaksi manusia (Marshal $C$ dan Rossman G.B, 1995). Menurut Poerwandari (2007) mengungkapkan bahwa penelitian kualitatif menghasilkan dan mengolah data yang sifatnya deskriptif, seperti transkip wawancara, catatan lapangan, gambar, foto, rekaman video, dan lain sebagainya.

Pengumpulan data dilakukan dengan wawancara mendalam (Indepth interview). Wawancara mendalam ini bertujuan untuk menggali lebih dalam pendapat umum informan berikut alasan-alasan yang melatar belakanginya Implementasi Undang Undang Nomor 6 Tahun 2014 Tentang Desa Di Desa Pentadio Timur Kecamatan Telaga Biru

Sumber data dalam penelitian ini menjadi rujukan yang meliputi :

1 Data primer, yaitu data yang diperoleh secara langsung dari objek yang diteliti, baik dari objek individual (informan) maupun dari suatu instansi-instansi atau badan lainnya untuk keperluan penelitian dari pengguna.

2 Data sekunder, yaitu data yang diperoleh secara tidak langsung untuk mendapatkan informasi (keterangan) objek yang diteliti, biasanya data tersebut diperoleh dari tangan kedua baik dari objek secara individual (responden/informan) maupun dari suatu badan (instansi) yang dengan sengaja melakukan pengumpulan data dari instansi-instansi atau badan lainnya untuk keperluan penelitian dari para pengguna. 
Untuk mendapatkan data dalam penelitian ini, baik data primer maupun data sekunder, dipergunakan beberapa teknik :

a. Observasi, yaitu secara langsung mengamati obyek yang menjadi kajian, terutama mengamati secara langsung masing-masing aparat dalam pelaksanaan tugas sehari-hari disamping mengamati cara kerja dan hasil kerja mereka.

b. Wawancara, yaitu melakukan tanya jawab langsung dengan para informan, dengan menggunakan pedoman wawancara.

Sumber-sumber data yang akan diwawancarai dalam penelitian ini adalah:

1) Kepala Desa 1 orang

2) Pendamping Desa 1 orang

3) Perangkat Desa Kaur/Kasi 2 orang

4) Anggota Badan Permusyawaratan Desa 2 orang

5) Masyarakat 2 orang

Sehingga keseluruhan dari informan yang di gunakan dalam penelitian ini adalah berjumlah 8 orang

c. Dokumentasi, yaitu menelaah dokumendokumen laporan dan melakukan dokumentasi atas suatu kejadian selama penelitian.

Analisis data telah mulai sejak merumuskan dan menjelaskan masalah, sebelum terjun kelapangan, dan berlangsung terus sampai penulisan hasil penelitian. Menurut Milse dan Huberman (dalam Sugiyono, 2012:337), mengemukakan bahwa aktivitas dalam analisis data kualitatif dilakukan secara interaktif dan berlangsung secara terus menerus sampai tuntas, sehingga datanya sudah jenuh.

Adapun langkah-langkah penelitian kualitatif dalam analis data di bagi kedalam tiga tahap, yaitu : Data Reduction (Reduksi Data), Data Display (Penyajian Data), dan
Conclusion Drawing (verification), Aktivitas dalam analisis data yaitu :

\section{Data Reducation (Reduksi Data)}

Mereduksi data berarti merangkum, memilih hal-hal yang pokok, memfokuskan pada hal-hal yang penting, dicari tema dan polanya. Dengan demikian data yang telah direduksi akan memberikan gambaran yang lebih jelas, dalam penelitian, sehingga kesimpulan akhir dari penelitian dapat di buat dan di verifikasi.

2. Data Display (Penyajian Data)

Data Display (Penyajian Data) dalam penelitian kualitatatif adalah penyajian data biasa dilakukan dalam bentuk uraian singkat, bagan, hubungan antar katagori, flowchart dan sejenisnya. Yang paling sering digunakan untuk penyajian data dalam penelitian kualitatif adalah dengan teks yang bersifat naratif. Sehingga dapat memudahkan untuk memahami apa yang terjadi, merancang kerja selanjutnya berdasarkan apa yang telah dipahami tersebut atau untuk pengecekan data yang sudah didisplaykan.

\section{Conclusion \\ Drawing/Verification}

(Penarikan Kesimpulan)

Conclusion Drawing/verification yaitu penarikan kesimpulan dan verifikasi. Kesimpulan dalam penelitian kualitatif adalah merupakan temuan baru yang sebelumnya belum pernah ada. Temuan dapat berupa deskripsi atau gambaran suatu obyek yang sebelumnya masih remengremeng atau gelap, sehingga setelah diteliti menjadi jelas, dapat berupa hubungan kausal atau interaktif, hipotesa atau teori.

Pada kegiatan analisis data, hal yang sangat perlu diperhatikan oleh para peneliti adalah checking data atau pemeriksaan data secara terus menerus untuk meyakinkan bahwa analisis data ini tetap berdasarkan pada data, bukan berdasarkan asumsi atau intuisi peneliti. Penelitian ini menggunakan 
analisis deskriptif kualitatif, yaitu menggambarkan data menggunakan kalimat untuk memperoleh keterangan yang jelas dan terperinci.

Untuk menjamin validitas data, dalam penelitian ini dilakukan teknik triangulasi yaitu (Sugiyono, 2008) untuk menguji keabsahan data dengan cara membandingkan keadaan dan perspektif seseorang dengan berbagai pendapat dan pandangan orang yaitu dari Informan yang di wawancarai terkait dengan Implementasi Undang Undang Nomor 6 Tahun 2014 Tentang Desa Di Desa Pentadio Timur Kecamatan Telaga Biru.

Adapun yang dimaksud dengan trianggulasi (triangulation) yaitu bahwa verifikasi dari penemuan dengan menggunakan berbagai sumber informasi dan berbagai metode pengumpulan data. Sedangkan trianggulasi yang digunakan dalam penelitian ini:

1. Trianggulasi sumber data, dilakukan dengan cara :

a. Membandingkan apa yang dikatakan secara pribadi,

b. Membandingkan data hasil wawancara dengan isi dokumen terkait.

c. Membandingkan apa yang dikatakan orang tentang situasi penelitian dengan apa yang dikatakan sepanjang waktu.

d. Membandingkan keadaan perspektif seseorang dari berbagai pendapat dan pandangan orang lain. Perbandingan ini akan memperjelas peneliti atas latar belakang alasanalasan terjadinya perbedaan pandangan tersebut.

Trianggulasi metode, yaitu dengan menggunakan lebih dari satu strategi penelitian untuk memperoleh sebuah informasi yang sama. Untuk itu dipergunakan dua cara, yaitu : mengecek derajat kepercayaan penemuan hasil beberapa teknik yang dipergunakan dalam pengumpulan data dan mengecek beberapa sumber data dengan metode yang sama. Pandangan trianggulasi metode dimaksudkan untuk memvariasikan dan memvalidasi analisis kualitatif.

\section{HASIL DAN PEMBAHASAN}

Untuk mengukur indikator Implementasi menurut teori George C. Edward III dalam Subarsono (2006:90) bahwa Implementasi Undang Undang Nomor 6 Tahun 2014 Tentang Desa Di Desa Pentadio Timur Kecamatan Telaga Biru bahwa sebagai berikut :

\section{Komunikasi}

Komunikasi merupakan aktifitas menyampaikan apa yang ada dipikiran, konsep yang kita miliki dan keinginan yang ingin kita sampaikan pada orang lain. Atau sebagai seni mempengaruhi orang lain untuk memperoleh apa yang kita inginkan. Komunikasi adalah kegiatan pengoperan lambang yang mengandung arti/ makna yang perlu dipahami bersama oleh pihak yang terlihat dalam kegiatan komunikasi. Dilihat dari beberapa definisi tersebut saling melengkapi. Definisi komunikasi secara umum adalah suatu proses pebentukan, penyampaian, penerimaan, dan pengolahan pesan yang terjadi didalam diri seseorang dan atau diantara dua atau lebih dengan tujuan tertentu. Definisi tersebut memberikan beberapa pengertian pokok yaitu komunikasi adalah suatu proses mengenai pembentukan, penyampaian, penerimaan dan pengolahan pesan.

Dalam hal ini hasil temuan oleh peneliti bahwa Komunikasi merupakan suatu proses atau kegiatan yang dilakukan seseorang, badan atau instansi untuk menyampaikan informasi kepada orang lain atau masyarakat 
dalam hal ini adalah suatu proses penyampaian informasi oleh Pemerintah Desa Pentadio Timur kepada masyarakat mengenai suatu kebijakan yang akan diterapkan dalam rangka untuk mencapai tujuan yang ditetapkan sudah cukup baik, hal tersebut penelitia melihat bahwa setiap ada kebijakan dan informasi maka pemerintah cepat memberikan informasi kepada masyarakt melalui forum rapat dan musyawarah desa.

Begitu halnya dengan hasil observasi di lapangan dengan hasil wawancara kepada informan bahwa komunikasi terus ada untuk kelangsungan organisasi Pemerintah desa terkait dengan anggaran dana desa yang berdasarkan pada regulasi, hal ini tentunya terus di terjaga oleh semua pihak guna memberikan citra positif pemerintah Desa Pentadio Timur dalam pengelola atas dana yang dianggarkan untuk keperluan pembanguan desa serta menerima informasi dari pemerintah lebih tinggi di atasnya serta menyampaikan informasi guna mensosialisasikan kepada masyarakat kebijakan tentang implementasi undang undang nomor 6 tahun 2014 tentang dana desa di Pentadio Timur kecamatan telaga biru.

Hasil temuan peneliti di lapangan melihat bahwa dengan komunikasi dalam sosialisasi ini sangat penting dilakukan karena dengan adanya sosialisai masyarakat dapat mengetahui informasi yang jelas mengenai kebijakan yang akan diterapkan pemerintah desa, dengan demikian pemerintaha desa telah siap dalam undang undang nomor 6 tahun 2014 tentang dana desa di Pentadio Timur Kecamatan Telaga Biru.

Penelititi dapat Dapat simpulkan yakni dengan koordinasi terus di lakukan agar hubungan baik antara lembaga dan masyarakat terus terjalin. koordinasi pemerintah desa Pentadio Timur berjalan dengn aktif secara vertikal guna mendapatkan informasi yang akuntabel, maka dapat di simpulkan bahwa komunikasi Pemerintah desa Pentadio Timur Kecamatan Telaga Biru selama ini sangat baik.

\section{Sumber Daya}

Sumber daya adalah unsur pelaksana yang juga mempunyai peranan yang sangat penting bagi implementasi kebijakan. Oleh sebab itu perlu tenaga yang ahli dan yang relevan dalam ukuran yang tepat, karena implementasi kebijakan tidak akan efektif kalau tidak ditangani oleh orang-orang yang ahli yang relevan dengan tugas-tugasnya. Sumber daya merupakan hal yang penting dalam implementasi kebijakan yang baik. Sumber daya yang dimaksud dalam penelitian ini adalah tersedianya sumbersumber pendukung implementasi kebijakan tersebut.

Sumber daya manusia merupakan keseluruhan penentuan dan pelaksanaan beberapa aktivitas, policy, dan program yang bertujuan untuk mendapatkan tenaga kerja, pengembangan dan pemeliharaan dalam usaha meningkatkan dukungannya terhadap peningkatan efektivitas organisasi dengan cara yang secara etis dan soslial dapat dipertanggungjawabkan. Aktivitas berarti melakukan berbagai kegiatan, misalnya melakukan perencanaan, peng organisasian, pengawasan, pengarahan, analisis jabatan, rekrutmen, seleksi, orientasi, memotivasi, dan lain-lain.

Dari sisi organisasi Pemerintah Desa Pentadio Timur sumber daya dibentuk untuk mencapai tujuan tertentu, dan apabila tercapai barulah dapat dikatakan berhasil. Untuk mencapai keberhasilan, diperlukan sumber daya manusia yang kompeten. Dengan demikian Sumber daya aparat Desa Pentadio Timur telah memenuhi kompetensi dalam menjalankan undang undang nomor 6 
tahun 2014 tentang dana desa di Pentadio Timur Kecamatan Telaga Biru.

Dalam pengamatan serta hasil wawancara peneliti melihat dalam struktur pindidikan terlihat menjadi sangat berguna untuk membantu organisasi meningkatkan kinerjanya terkait kompetensi aparat desa Pentadio Timur sangat diperlukan dalam setiap proses sumber daya manusia.

Maka peneliti dapat menyimpulkan bahwa Sumber Daya Manusia di desa pentadio baik dari aparatnya, lembaga lainya yang berbasis kompetensi dapat meningkatkan kapasitas dan membangun pondasi organisasi kuat dan hebat, apabila orang-orang yang bekerja dalam organisasi itu memiliki kompetensi yang tepat sesuai dengan tuntutan pekerjaannya, maka dia akan mampu baik dari segi pengetahuan, keterampilan maupun mental serta karakter produktifnya hal tersebut telah nampak di Desa Pentadio Timur bahwa sumber daya sudah cukup memadai bahkan menghasilkan sebuah kinerja yang maksimal.

\section{Disposisi}

Dalam implementasi kebijakan tidak boleh terjadi kesenjangan antara pembuat dan implementator kebijakan dan hendaknya diantara keduanya terjalin hubungan yang mendukung agar implementasi kebijakan dapat berhasil dengan baik. Disposisi merupakan keingginan atau kesepakatan dikalangan aktor untuk implementasi kebijakan secara efektif, pelaksana bukan hanya mengetahui apa yang harus mereka kerjakan dan memiliki kemampuan untuk implementasi kebijakan tersebut.

Tidak dapat dipungkiri dan diragukan lagi bahwa salah satu faktor yang paling penting dan mampu menentukan keberhasilan dan kegagalan suatu organisasi adalah fakor sikap dari sumber daya manusianya. Sikap adalah satu faktor utama dalam mendukung semua aspek baik dari pengetahuan dan kemapuan seseorang.

Sesuai dengan kesimpulan hasil wawancara sebelumnya bahwa dari sudut pandang terkait peranan aparat desa dalam pengelolaan anggran dana desa sudah baik serta di dukung oleh lembaga badan permusyawaratan Desa Pentadio Timur sebab merekalah yang beraada di masyarakat menjalankan fungsinya serta sikap dalam mengemban sebuah tugas dalam pengelolan anggaran dana desa penuh komiten dan berpeanga teguh pada sebuah hirarki organisasi.

Dalam menjalankan peranya sikap aparat desa bekerja dengan baik melayani kepada masyarakat terhadap sistem nilai yang dianutnya. Upaya pengembangan sikap aparat Desa Pentadio Timur dalam memberikan pemahaman mengenai pentingnya dalam melaksanakan tugas, menjelaskan sasaran yang hendak dicapai serta harapan atau peran serta lembaga lainya dalam mensukseskan sasaran yang hendak dicapai.

Maka dengan demikian dapat di simpulkan bawa dari pengamatan peneliti dan hasil wawancara terlihat sangat jelas bahwa Desa Pentadio Timur benar telah bersikap baik dalam hal implementasi undang-undang nomor 6 tahun 2014 tentang desa.

\section{Struktur birokrasi}

Struktur birokrasi berkenaan dengan kesesuain organisasi birokrasi yang menjadi penyelenggara implementasi kebijakan publik. Tantangannya adalah bagaimana agar tidak terjadi bureaucratic fragmentation karena struktur ini menjadikan proses implementasi menjadi jauh dari efektif. walaupun variabel lainnya sudah terpenuhi dengan baik dalam pelaksanaan kebijakan. Namun karena struktur birokrasi yang lemah. Kebijakan yang begitu kompleks menuntut 
adanya kerja sama banyak orang, ketika struktur birokrasi tidak kondusif pada kebijakan yang tersedia, maka hal ini akan menghambat jalannya kebijakan. Birokrasi sebagai pelaksana sebuah kebijakan harus dapat mendukung kebijakan yang telah diputuskan secara politik dengan melakukan koordinasi dengan baik. Struktur birokrasi merupakan faktor penting dalam melaksanakan suatu kebijakan, tanpa didukung dengan struktur birokrasi yang baik, kebijakan yang akan dilaksanakan tidak akan maksimal.

Menurut Robbins (1996:12) struktur organisasi memiliki tiga komponen atau dimensi, yaitu : 1) Kompleksitas, ialah tingkat diferensiasi atau pembagian kerja yang ada dalam organisasi baik secara hirarki maupun unit-unit organisasi yang tersebar secara geografis. Bahwa kompleksitas adalah sejumlah perbedaan pekerjaan atau sejumlah aktivitas fungsi yang dilaksanakan oleh organisasi. Semakin kompleks organisasi semakin sulit dalam mengelola pekerjaan manajerial karena terdapat ketidaksamaan baik dalam unit/kelompok tugas maupun pekerjaan individu. 2) Formalisasi, ialah penggunaan peraturan dan prosedur yang tertulis untuk menstandarisasi beberapa operasi organisasi. Selain itu, formalisasi mengacu pada perluasan ekspektasi kerja, aturanaturan, dan kebijakan-kebijakan perilaku yang diharapkan dan dinyatakan dalam bentuk tertulis. 3) Sentralisasi, ialah letak dari pusat pengambilan keputusan dalam suatu organisasi. Sentralisasi terkait dengan partisipasi dan otonomi, yang dalam praktek sulit untuk dikenali karena keputusan dapat dibuat oleh setiap individu dalam organisasi.

Ketidakpatuhan lembaga badan permusywaratan desa menjunjung komitmen mensejahterkan masyrakat dalam implementasi undang undang nomor 6 tahun
2014 tentang pengelolaan dana desa, belum di rasakan oleh masyarakat hal tersebut membuat alur pelayanan sangat terganggu, serta membuat masyarakat bingung kemana mereka harus mendapatkan pelayanan, dan terkdang sebuah kebijakan menjadi tidak pasti.

Dari uraian di atas dapat di simpulkan bahwa desa pentadio telah mempunyai SOP dan struktur birokrasi yang Baik dalam sebuah implementasi undang undang nomor 6 tebtang pengelolaan dana desa serta Kedudukan, Susunan Organisasi, Tugas dan Fungsi, telah di terapkan, Namun melihat secara internal dalam sebuah organisasi pemerintah desa serta menganalisis dari hasil wawancara dengan bebrapa informan bahwa pada kenyataan masih ada kebijakan yang tumpang tindih baik dari tingkat atas sampai ke tingkat bawah, hal ini terlihat pada pengambilan sebuah kebijakan yang semestinya di lakukan oleh pemerintah desa justru di ambil alih oleh badan permuswaratan desa dalam hal pengambilan kebijakan sebuah anggaran dana desa tentunya hal ini tidak sesuai dengan amanat undang-undang nomor 6 tahun 2014 tentang desa serta dapat mencederai struktur birokrasi.

\section{KESIMPULAN}

Dari empat indikator yakni Komunikasi, Sumberdaya, Disposisi, Struktur birokrasi untuk mengukur implementasi Menurut George C. Edward III dalam Subarsono maka dapat di simpulkan bahwa semua variable, sudah baik meskipun masih ada salah satu variable yang terlihat kurang baik yakni :

1. Komunikasi desa Pentadio Timur sudah baik kerena selama ini sosialisasi serta koordinasi baik dengan pemerintah daerah dan pusat terus terjalin dalam menerapkan 
Undang Undang Nomor 6 Tahun 2014 tentang dana desa di Pentadio Timur Kecamatan Telaga Biru.

2. Sumberdaya dan Disposisi salah satu roda penggerak organisasi pemerintahan desa Pentadio Timur terlihat pada SDM yang sudah memadai dan dukungan masyarakat dalam menajalankan sebuah Undang Undang tentang dana desa di Pentadio Timur Kecamatan Telaga Biru juga sangat mendukung

Struktur birorasi sudah memenuhi standar namun saat ini menunjukkan bahwa masih adanya ketimpangan dalam menjalankan tugas dan fungsi organisasi dalam pengambilan kebijakan, misalnya pengambilan keputusan atas anggaran yang sebaiknya pemerintah desa namun di kotomi oleh lembaga badan permusyaratan desa hal ini tentunya mendapat nilai kurang baik dalam struktur organisasi di desa Pentadio Timur Kecamatan Telaga biru.

\section{SARAN}

Dari hasil penelitian dan kesimpulan yang ada, dengam melihat Undang Undang Nomor 6 Tahun 2014 tentang dana desa di Pentadio Timur Kecamatan Telaga Biru. maka peneliti dapat mengemukan saran saran sebagai berikut :

1. Pemerintah Desa Pentadio Timur Kecamatan Telaga Biru diharapkan bisa meningkatkan kualitas pelayanan publik kepada masyarakat khususnya pada Anggaran Dana Desa sesuai dengan amanat Undang-Undang Nomor 6 Tahun 2014 Tentang Desa.

2. $\mathrm{Di}$ harapkan lembaga badan permuswaratan desa (BPD) kembali pada tupoksi kelembagaan Dalam menampung aspirasi masyarakat
Undang-Undang Nomor 6 Tahun 2014 Tentang Desa sehingga tidak ada lagi kebjikan yang tumpang tindih.

\section{REFERENSI}

Edwards III, George C. 1980. Implementing Public Policy. Washington: Cogressional Quaerterly Inc.

Marshal, C \& Rossman, G.B., (1995). Designing Qualitative Research. California: Sage Publication Inc.

Poerwandari, E.K. (2007). Pendekatan Kualitatif dalam penelitian Psikologi. Jakarta: LPSP3 Universitas Indonesia

Robbins, Stephen P. 1996. Perilaku Organisasi Edisi ke 7 (Jilid II). Jakarta : Prehallindo

Subarsono, AG, Analisis Kebijakan Publik:Konsep, Teori dan Aplikasi, Pustaka Pelajar, Yogyakarta, 2006

Syaukani, ad all, 2004, Otonomi Daerah Dalam Negara Kesatuan, Pustaka Pelajar, Yogyakarta

Sugiyono. 2012. Metode Penelitian Kuantitatif Kualitatif dan R\&B. Bandung: Alfabeta.

Undang-Undang No 5 tahun 1979 tentang Pemerintahan Desa

Undang-Undang No 32 Tahun 2004 tentang Otonomi daerah

Undang-Undang No 6 Tahun 2014 tentang Desa

Peraturan Pemerintah (PP) Nomor 22 Tahun 2015 yang direvisi dari PP No 60 Tahun 2014 tentang Dana Desa yang bersumber dari APBN.

Peraturan Menteri Dalam Negeri Republik Indonesia Nomor 110 Tahun 2016 Tentang Badan Permusyawaratan Desa 